\title{
PERAN TEKNOLOGI MULTIMEDIA DALAM MENYAJIKAN KONSEP-KONSEP KIMIA PADA TINGKAT MAKROSKOPIS, MIKROSKOPIS, DAN SIMBOLIS

\section{Abstrak}

Pemanfaatan teknologi multimedia dalam bidang pendidikan sangat menunjang efesiensi dan efektivitas proses belajar mengajar. Penggunaan multimedia dalam pendidikan dapat menggiring pebelajar ke dalam pengalaman multisensori untuk promosi belajar. Dalam bidang kimia, multimedia dimanfaatkan untuk menyajikan konsep-konsep kimia pada tingkat makroskopis, mikroskopis, dan simbolis. Multimedia dapat menjelaskan konsep-konsep abstrak melalui animasianimasi , sehingga, kimia yang dipandang oleh sebagian orang sebagai ilmu yang sulit dipahami, akan menjadi lebih mudah dipahami. Multimedia dapat mengkombinasikan suara, animasi, gambar, dan video secara bersamaan serta melibatkan semua panca inderanya dan mengembangkan gaya belajar yang disukainya. Salah satu hasil penelitian menemukan implikasi dari penggunaan multimedia dalam pembelajaran kimia yaitu mendorong pebelajar aktif, terorganisaasi, dan dapat mengintegrasikan informasi yang diperoleh untuk memahami konsepkonsep dan prinsip yang sulit serta dapat digunakan untuk memecahkan masalah.

Kata Kunci: konsep kimia, media pembelajaran, multimedia, makroskopis, mikroskopis, simbolis.

\section{A. PENDAHULUAN}

Kesulitan dalam penguasaan materi mata kuliah Kimia merupakan kasus tipikal yang sering terjadi dan meliputi sebagian besar populasi mahasiswa dari berbagai institusi kependidikan. Bagi mahasiswa dengan disiplin ilmu yang tidak berfokus kepada ilmu kimia, kasus ini seringkali lebih menonjol. Isu sentral dalam pendidikan kimia adalah hubungan antara makroskopik atau dunia nyata dan molekular. Pebelajar akan dapat memahami lebih baik ilmu kimia dan mengaplikasikan ilmu yang mereka pahami untuk memecahkan masalah jika mereka dapat mendalami hubungan antara ke dua isu sentral tersebut (Vermat \& Henny, 2003).
Perkembangan ilmu pengetahuan dan teknologi semakin mendorong upaya-upaya pembaharuan dalam pemanfaatan hasil-hasil teknologi dalam bidang pendidikan. Arsyad, mengemukakan, dalam proses belajar mengajar, dua unsur yang amat penting adalah metode mengajar dan media pembelajaran. Kedua aspek ini saling berkaitan. Pemakaian media pembelajaran dalam proses belajar mengajar dapat membangkitkan keinginan dan minat yang baru, membangkitkan motivasi dan rangsangan kegiatan belajar, dan bahkan membawa pengaruh-pengaruh psikologis terhadap siswa. Media pembelajaran juga

*) Ida Ayu Anom Arsani, S.Si., M.Pd., adalah Dosen Mata Kuliah Kimia Terapan di Jurusan Teknik Mesin Politeknik Negeri Bali 
membantu siswa meningkatkan pemahaman materi yang disampaikan. Dalam proses belajar mengajar, media mempunyai arti yang cukup penting, karena dalam kegiatan tersebut ketidak jelasan bahan yang disampaikan dapat dibantu dengan menghadirkan media sebagai perantara (Arsyad, 2005).

Middlecamp dan Kean, mengungkapkan bahwa ilmu kimia memiliki karakteristik tersendiri dibandingkan dengan ilmu pengetahuan lainnya, terutama dalam penyampaian pada proses belajarmengajarnya (Middlecamp dan Kean, 1985). Piaget sebagaimana di kutip Sastrawijaya, mengatakan bahwa ilmu kimia banyak membahas masalah obyek konkrit dalam skala makroskopis dan mikroskopis sehingga memerlukan model (Sastrawijaya, 1998). Mayer, menemukan implikasi dari penggunaan multimedia dalam pembelajaran kimia yaitu mendorong pebelajar aktif, terorganisaasi, dan dapat mengintegrasikan informasi yang diperoleh untuk memahami konsep-konsep dan prinsip yang sulit serta dapat digunakan untuk memecahkan masalah (Mayer, 2003). Program multimedia kimia didesign untuk memperlihatkan ilustrasi dan konsep-konsep kunci ilmu kimia melalui animasi, grafik model-model molekul, dan persamaan-persamaan, sehingga dapat memotivasi pebelajar untuk mempelajari konsep-konsep sulit dalam ilmu kimia.

Penggunaan animasi untuk menjelaskan proses kimia pada tingkat molekul adalah diusulkan sebagai cara untuk meningkatkan pemahaman pebelajar. Rieber (dalam Garnet, P, dkk.), menyarankan suatu kerangka kerja sebagai panduan yang sesuai digunakan untuk animasi dan penyajian visual dinamik dalam mempelajari materi pelajaran. Penggunaan media pembelajaran tidak hanya memberikan pengalaman yang konkrit, tetapi juga membantu pebelajar mengintegrasikan pengalamannya. Penyajian konsep-konsep kimia memerlukan media yang dapat menampilkan gambargambar baik yang statis maupun dinamis untuk memvisualisasikan konsep-konsep yang abstrak, yaitu dengan memanfaatkan teknologi multimedia.

\section{B. APLIKASI MEDIA DALAM PEMBELAJARAN}

Penerapan teknologi dalam bidang pendidikan khususnya kurikukum adalah dalam dua bentuk, yaitu bentuk perangkat lunak (software) dan perangkat keras (hardware). Penerapan teknologi dalam perangkat keras dalam pendidikan dikenal sebagai teknologi alat (tool technology), teknologi ini lebih menekankan kepada penggunaan alatalat teknologis untuk menunjang efesiensi dan efektivitas pendidikan khususnya dalam proses belajar mengajar, seperti penggunaan media.

Pada mulanya media hanya dianggap sebagai alat bantu mengajar, akan tetapi saat ini telah banyak dikembangkan program pengajaran yang memadukan bahan ajar dengan media yang digunakan dalam bentuk kaset audio. Media memiliki kemampuan merangsang terjadinya proses belajar yang efektif dan efesien.

Kemampuan tersebut adalah (1) menghadirkan obyek lingkungan sekitar ke dalam lingkungan belajar, (2) membuat konsep abstrak menjadi konkrit, (3) mampu menyamakan persepsi, (4) mengatasi hambatan waktu, tempat, jumlah dan jarak, dan (5) memvisualisasikan aplikasi pemecahan masalah suatu peralatan dan prosedur kerja serta cara penggunaan alat. Menurut Kemp dan Dayton (dalam Arsyad), media pembelajaran dapat memenuhi tiga fungsi utama, yaitu (1) memotivasi minat dan tindakan, (2) menyajikan informasi, dan (3) memberi instruksi (Arsyad, 2005).

Pemanfaatan media dalam pembelajaran banyak tergantung pada persepsi pendidik. Hardjito (dalam Sutrisno, dkk.), pendidik yang mempunyai persepsi positif terhadap peran media, akan memanfaatkan media dalam pembelajaran. Media merupakan bagian integral dari proses belajar mengajar dan apapun media yang digunakan sasarannya akhirnya adalah untuk 
memudahkan belajar (Sutrisno, dkk., 2006).

Media akan bermakna bila dalam pembuatannya diselaraskan dengan perubahan tingkah laku pebelajar sebagai pengguna media dan disesuaikan dengan tujuan pembelajaran yang akan dicapai. Media dalam pemanfaatannya diharapkan dapat membantu pebelajar untuk belajar secara aktif karena adanya interaksi fisis dan kognitif. Dengan pembelajaran yang aktif dari pebelajar akan mempertahankan perhatian, meningkatkan prestasi, dan membentuk pengetahuan baru.

Menurut Hamalik, penggunaan media pembelajaran dalam proses belajar mengajar dapat membangkitkan keinginan dan minat yang baru, membangkitkan motivasi dan rangsangan kegiatan belajar, dan bahkan pengaruh-pengaruh psikologis terhadap siswa (Arsyad, 2005).

Selain membangkitkan motivasi, media pembelajaran dapat membantu siswa meningkatkan pemahaman, menyajikan data dengan menarik dan terpercaya, memudahkan penafsiran data, dan memadatkan informasi. Media pembelajaran juga dapat digunakan untuk menyalurkan pesan (bahan pembelajaran), sehingga dapat merangsang perhatian, minat, pikiran, dan perasaan pebelajar dalam kegiatan belajar untuk mencapai tujuan pembelajaran tertentu.

Pemilihan media dalam proses belajar mengajar sangat perlu mempertimbangkan beberapa faktor, yaitu tujuan pembelajaran, keefektifan, karakteristik pebelajar, ketersediaan biaya, dan kualitas teknis. Dasar pertimbangan pemilihan media sangatlah sederhana yaitu dapat memenuhi kebutuhan atau mencapai tujuan yang diinginkan atau tidak (Sadiman, dkk., 2005). Tujuan dari penggunaan multimedia dalam pendidikan dan pelatihan adalah untuk menggiring pebelajar ke dalam pengalaman multisensori untuk promosi belajar (Henich, dkk., 2005). ). Secara keseluruhan, multimedia terdiri dari tiga level (Mayer, 2001) yaitu:

a. Level teknis, yaitu multimedia berkaitan dengan alat-alat teknis ; alat-alat ini dapat diartikan sebagai wahana yang meliputi tanda-tanda (signs).

b. Level semiotik, yaitu representasi hasil multimedia seperti teks, gambar, grafik, tabel, dan lain lain.

c. Level sensorik, yaitu yang berkaitan dengan saluran sensorik yang berfungsi untuk menerima tanda (signs).

Beberapa ahli mengemukakan keuntungan dari penggunaan multimedia dalam pembelajaran:

a. Pembelajaran aktif

Pembelajaran

dengan

memanfaatkan multimedia melibatkan pebelajar secara aktif, belajar melalui interaksi fisis dan kognitif. Pembelajaran aktif dapat mempertahankan perhatian, meningkatkan prestasi, dan membentuk pengetahuan baru (Oblinger, 1993).

b. Mendorong eksplorasi

Program multimedia dapat membantu pebelajar mengembangkan model mental sebagai dasar untuk pembelajaran selanjutnya, membentuk lingkungan yang memungkinkan bagi pengajar dan pebelajar untuk melakukan eksplorasi, membantu pebelajar mengembangkan domain perspektifnya dan mengembangkan susunan pengetahuan terintegrasi yang membantu pebelajar mentransfer pengetahuan ke dalam bentuk yang komplit (Fryer, 1994).

c. Motivasi

Teknologi dapat menginspirasikan pebelajar dengan membuat pembelajaran lebih interaktif dan relevan, sehingga pebelajar dapat menimati bekerja bersama teknologi dan karenanya dapat bekerja lebih lama dan ini merupakan keuntungan jangka panjang (Summer, 1990). 
d. Pelibatan multisensori

Beberapa pebelajar mempunyai gaya belajar yang berbeda. Dengan pembelajaran multimedia, pebelajar dapat melibatkan semua panca indranya dan mengembangkan gaya belajar yang disukainya (gaya belajar visual, audio, dan audio visual).

\section{PERAN TEKNOLOGI MULTIMEDIA DALAM PEMBELAJARAN KIMIA}

Isu sentral dalam pendidikan kimia adalah hubungan antara makroskopik atau dunia nyata dan molekular. Pebelajar akan dapat memahami lebih baik ilmu kimia dan mengaplikasikan ilmu yang mereka pahami untuk memecahkan masalah jika mereka dapat mendalami hubungan antara ke dua isu sentral tersebut (Vermat \& Henny, 2003). Tujuan utama dari pendidikan kimia adalah pebelajar mendapatkan konsep-konsep kunci dan prinsip-prinsip, seperti: ikatan, struktur, reaktifitas, kesetimbangan, keasaman, dan lain-lain.

Gabel 1993 (dalam Russel dan Kozma, 1997), menyebut ada tiga penyebab kesulitan yang dimiliki dalam mengembangkan pemahaman konsep kimia, yaitu:

a. Pengajaran kimia dapat menimbulkan tekanan dalam memecahkan masalah pada tingkat simbolis, gejala fenomena dan tingkat partikel.

b. Pengajaran kimia berlangsung pada tingkat makroskopis, mikroskopis, dan simbolis. Hubungan ketiga tingkatan itu tidak cukup disimpan dalam memori jangka panjang siswa.

c. Siswa belum mampu memahami hubungan silang ketiga tingkatan, jika fenomena kimia yang dihadapi tidak berhubungan dengan kehidupan sehari-hari.

Ketiga tingkatan dalam menyajikan konsep-konsep kimia dapat digambarkan sebagai berikut:

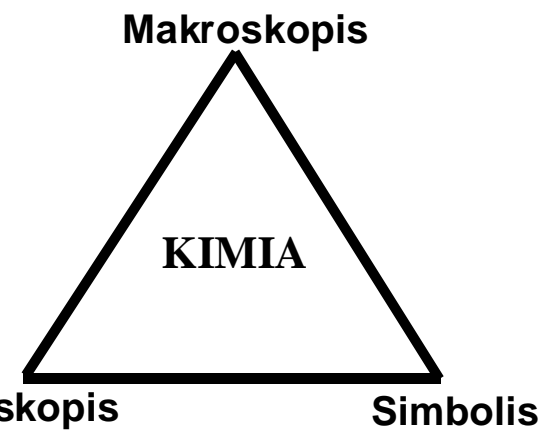

Gambar 1. Tiga Tingkatan Penyajian Konsep Kimia (Diadaptasi dari : Three Basic Components Representation of Chemistry; Johnstone ;1993)

Tingkat makroskopis mengacu pada fenomena kimia yang konkrit yang dapat diamati dan dirasakan oleh indera kita tanpa bantuan alat, seperti: warna dan bau. Tingkat mikroskopis mengacu pada sesuatu yang abstrak yang memerlukan bantuan alat untuk menjelaskan, seperti: atom, elektron, ikatan, dan lain-lain. Model tingkat simbolis mengacu pada penyajian persamaan stoikiometri dan grafik-grafik. Multimedia juga dapat membantu menjelaskan beberapa proses yang nyata dengan konsep-konsep abstrak dari atom-atom, molekul, dan ionion.

Aplikasi multimedia dalam pembelajaran kimia sangatlah penting untuk membantu meningkatkan pemahaman dan minat pebelajar dalam mempelajari ilmu kimia, karena multimedia berisi kombinasi antara teks, grafik, animasi, suara, dan video.

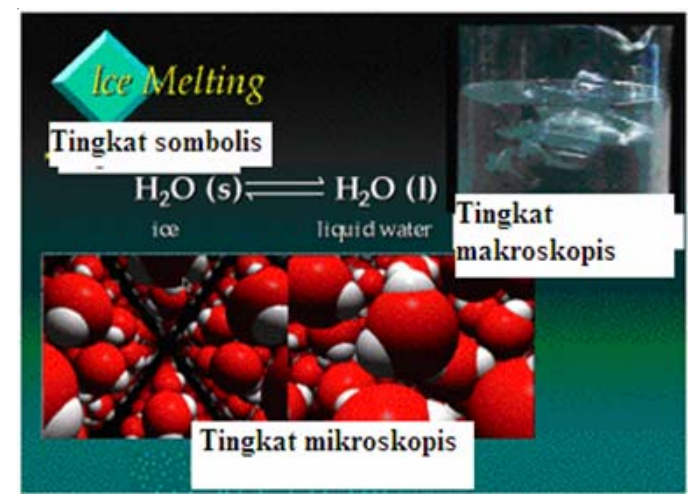

Gambar 2. Penerapan Tiga Tingkatan Penyajian Konsep Kimia (Diadaptasi dari: Vischem Animations, http://vischem.cadra.com.au) 
Kombinasi ini merupakan kesatuan yang secara bersama-sama menampilkan informasi, pesan, dan isi pelajaran. Penggunaan teknologi multimedia untuk mengajar kimia mempunyai pengaruh yang signifikan terhadap motivasi belajar, prestasi pebelajar dan sikap (Loretta \& Stanley, 1993).

Mayer, menemukan implikasi dari penggunaan multimedia dalam pembelajaran kimia yaitu mendorong pebelajar aktif, terorganisaasi, dan dapat mengintegrasikan informasi yang diperoleh untuk memahami konsepkonsep dan prinsip yang sulit serta dapat digunakan untuk memecahkan masalah (Mayer, 2003).

Program multimedia kimia didesign untuk memperlihatkan ilustrasi dan konsepkonsep kunci ilmu kimia melalui animasi, grafik model-model molekul, dan persamaan-persamaan, sehingga dapat memotivasi pebelajar untuk mempelajari konsep-konsep sulit dalam ilmu kimia.

Program multimedia dengan bantuan komputer adalah metode baru dalam mengajar kimia. Penelitian intensif dengan pendekatan konstruktivistik dan instruksi media komputer, mendorong digunakannya komputer sebagai inovasi dalam mengajar dan pembelajaran sain (Talib,dkk., 2005). Komputer membantu pengajar maupun pebelajar mengeksplorasikan konsep-konsep kimia pada tingkat makroskopis, submikroskopis, dan simbolis. Aplikasi dinamis yang sangat potensial digunakan untuk menstimulasi pebelajar mencapai tujuan belajar adalah melalui animasi. Penggunaan animasi untuk menjelaskan proses kimia pada tingkat molekul adalah diusulkan sebagai cara untuk meningkatkan pemahaman pebelajar. Rieber (dalam Garnet, P, dkk., tanpa tahun.) menyarankan suatu kerangka kerja sebagai panduan yang sesuai digunakan untuk animasi dan penyajian visual dinamik dalam mempelajari materi pelajaran.
Catrambone dan Stasco 1999 (dalam Talib,dkk., 2005) mendefinisikan animasi adalah suatu proses gerakan dan perubahan beberapa objek pada layar komputer sebagai suatu simulasi dari teori dinamis, abstrak, dan perkembangan proses dari suatu kejadian atau fenomena.

\section{IMPLIKASI MULTIMEDIA DALAM PEMBELAJARAN KIMIA}

Penggunaan teknologi multimedia dapat mengintegrasikan semua jenis pengalaman belajar, prinsip-prinsip dapat dipresentasikan dan diilustrasikan dalam waktu yang bersamaan (Loretta \& Stanley, 1993). Menyajikan proses kimia untuk pebelajar dengan visualisasi sangat ditekankan dalam pendidikan kimia, karena dapat membantu pebelajar mengembangkan pemahaman terhadap konsep-konsep kimia (Yang \& Andre, 2003).

Beberapa keuntungan penggunaan multimedia dalam pembelajaran kimia yakni:

a. Multimedia mempermudah mempelajari konsep-konsep dan prinsip

b. Multimedia adalah suatu proyek yang mempunyai target mempelajari konsep-konsep kimia yang sulit (Stieff \& Wilensky, 2003).

c. Multimedia untuk investigasi di laboratorium

d. Multimedia dapat membantu pebelajar memanipulasi dan mengamati berbagai sajian sebelum eksperimen kimia dilakukan. Mereka dapat membuat dan menganalisis penyajian eksperimen mereka ( Schank \& Kozma, 2002).

\section{E. KESIMPULAN DAN SARAN}

1. Kesimpulan

Berdasarkan pembahasan tentang peran teknologi multimedia dalam menyajikan konsep-konsep kimia pada tingkat makroskopis, mikroskopis, dan simbolis, bahwa 
pemanfaatan teknologi multimedia dalam pembelajaran kimia dapat menunjang efisiensi dan efektivitas proses belajar mengajar. IImu kimia yang sebagian besar mengandung konsep-konsep abstrak, dapat dijelaskan dengan proses-proses nyata melalui visualisasi baik yang statik maupun dinamik. Proses penyajian kimia dengan visualisasi sangat ditekankan dalam pendidikan kimia, karena dapat membantu pebelajar mengembangkan pemahaman terhadap konsepkonsep kimia dan mengurangi terjadinya miskonsepsi.

\section{Saran}

Penggunaan multimedia dalam pembelajaran kimia hendaknya diterapkan di sekolah-sekolah ataupun di kampus-kapus, karena ia dapat meningkatkan motivasi dan pemahaman pebelajar terhadap kimia. Kendala yang banyak dihadapi dalam implementasinya adalah keterbatasan infrastruktur yang dimiliki oleh sekolah-sekolah maupun kampus. Akan tetapi dengan adanya peningkatan anggaran pendidikan, diharapkan hal ini dapat diatasi, karena penggunaan teknologi multimedia untuk mengajar kimia mempunyai pengaruh yang signifikan terhadap motivasi belajar dan prestasi pebelajar dan sikap.

\section{DAFTAR PUSTAKA}

Arsyard. 2005. Media Pembelajaran. Jakarta: PT Raja Grafindo Persada

Fryer, B.1994. Multimedia Training. Multimedia World 1(7): 55-59.

Garnet, P., Oliver, R. \& Hackling, M. Tanpa Tahun. Designing Interactive Materials to Support Concept Development in Beginning Chemistry Class, (online), (http://elrond.scam.ecu.edu.au/oliver/ docs/98/ICCE.pdf,

Henich, R., Smaldino, Shoron, E. \& James, R.D. 2005. Instrutional Technology and Media for Learning. New Jersey : Person Merrill Prentice.

Johnstone, A.H. 1993. The Developments of Chemistry Teaching. Journal of Chemical Education, 70, 701705.
Loretta, L.J. \& Stanley, S.G. 1993. Multimedia Technology: A Catalyst for Change In Chemical Education. Pure and Applied Chemistry. 65(2): 245248

Mayer, R. 2003. Multimedia Learning. Cambridge University Press, Cambrigde, UK

Midde, C. \& Kean, E. 1985. Panduan Belajar Kimia Dasar. Jakarta: Gramedia

Oblinger, D. 1993. Multimedia in Instruction. Chapel Hill, NC: The Institute for Acaddemic Technology.

Russel, W.J. \& Kozma, B.R. 1997. Use of Simultaneous-Synchronized Macroscopic, Microscopic, and Symbolic Representations to Enchance the Teaching and Learning of Chemistry Concept. Journal of Chemical Education, 74(3): 330-334.

Sadiman, S.A., Raharjo, S., Anung, H.R. \& Rahardjito. 2005. Media Pendidikan Pengertian, Pengembangan, dan Pemanfaatannya. Jakarta:PT RajaGrafindo Persada.

Sastrawijaya, T. 1988. Proses Mengajar Kimia. Jakarta: P2LPTK Dirjen Dikti Depdikbud.

Schank, P., \& Kozma, R. 2002. Learning Chemistry Through The Use of A Representation-Based Knowledge Building Environment. Journal of Computers in Mathematics and Science Teaching, 21(3): 253-279

Stieff, Mike \& Wilensky, Uri. 2003. Connected Chemistry-Incorporating Interactive Simulations into the Chemistry Classroom. Journal of Science Education and Technology, 12(3): 286-287

Summer, J.A. 1990-1991. Effect of Interactivity upon Student Achievement, Completion Intervals, and Affective Reception. Journal of Educational Technology System, 19(1): 53-57

Suparman, A. 1997. Desain Instruktional. Jakarta: Dirjen Dikti, Depdikbud

Sutrisno, Taufik, D. \& Sugiyono, A. 2006. Profil Pemanfaatan Media Pembelajaran dalam Menciptakan Perkuliahan yang Kondusif di Universitas Negeri Malang. Jurnal Pendididkan \& Pembelajaran. 13(1): 54-62

Talib, Robert, M. \& Margaret, S. 2005. ComputerAnimated Instruction and Students' Conceptual Change in Electrochemistry: Preliminary Qualitative Analysis. International Education Journal, 5(5): 2942

Vermat, H. \& Henny, K.P. 2003. The Use Animation In Chemical Education. Stanford Research Institute, (online),

(http://www.rsc.org/images/lssue6-3 tcm18-33086.pdf Yang, E. \& Andre, T. 2003. Spatial Ability and the Impact of Visualization/Animation on Learning Electrochemistry. International Journal of Science Eduation, 25(3): 329-349.

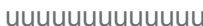

